\title{
Mass spectrometry-based identification and whole-genome characterisation of the first pteropine orthoreovirus isolated from monkey faeces in Thailand
}

\author{
Nathamon Kosoltanapiwat ${ }^{1 *}$ (D), Onrapak Reamtong ${ }^{2}$, Tamaki Okabayashi, ${ }^{3,4}$, Sumate Ampawong ${ }^{5}$, \\ Amporn Rungruengkitkun ${ }^{1}$, Tipparat Thiangtrongjit ${ }^{2}$, Narin Thippornchai ${ }^{1}$, Pornsawan Leaungwutiwong ${ }^{1}$, \\ Aongart Mahittikorn ${ }^{6}$, Hirotake Mori ${ }^{6}$, Thanada Yoohanngoa ${ }^{1}$ and Prechaya Yamwong ${ }^{1}$
}

\begin{abstract}
Background: The pteropine orthoreovirus (PRV) was isolated from monkey (Macaca fascicularis) faecal samples collected from human-inhabited areas in Lopburi Province, Thailand. These samples were initially obtained to survey for the presence of hepatitis E virus (HEV).

Results: Two virus isolates were retrieved by virus culture of 55 monkey faecal samples. Liquid chromatographytandem mass spectrometry (LC-MS/MS) was successfully used to identify the viruses as the segmented dsRNA orthoreovirus. Phylogenetic analysis of the Lopburi orthoreovirus whole-genomes revealed relationships with the well-characterised PRVs Pulau (segment L1), Cangyuan (segments L2, M3 and S3), Melaka (segments L3 and M2), Kampar (segments M1 and S2) and Sikamat (segments S1 and S4) of Southeast Asia and China with nucleotide sequence identities of 93.5-98.9\%. RT-PCR showed that PRV was detected in 10.9\% (6/55) and HEV was detected in $25.5 \%(14 / 55)$ of the monkey faecal samples.

Conclusions: PRV was isolated from monkey faeces for the first time in Thailand via viral culture and LC-MS/MS. The genetic diversity of the virus genome segments suggested a re-assortment within the PRV species group. The overall findings emphasise that monkey faeces can be sources of zoonotic viruses, including PRV and HEV, and suggest the need for active virus surveillance in areas of human and monkey co-habitation to prevent and control emerging zoonotic diseases in the future.
\end{abstract}

Keywords: Monkey, Macaque, Macaca fascicularis, Orthoreovirus, Hepatitis E virus, Mass spectrometry

\section{Background}

In some areas in Lopburi Province, Thailand, humans and monkeys, mostly macaques, live in close contact. In these areas, faeces excreted by the animals can unavoidably contaminate the human environment. Faeces are sources of pathogens, including bacteria, parasites and viruses. Most enteric viruses typically present in faeces are non-enveloped viruses that can exist outside the host

\footnotetext{
* Correspondence: nathamon.kos@mahidol.ac.th

'Department of Microbiology and Immunology, Faculty of Tropical Medicine, Mahidol University, 420/6 Ratchawithi Road, Ratchathewi, Bangkok 10400,

Thailand

Full list of author information is available at the end of the article
}

for several days [1, 2]. Some of these are zoonotic viruses that can infect both humans and animals. Hence, in areas in which humans and animals co-inhabit, the potential for zoonotic transmission is elevated, requiring observation and control.

Pteropine orthoreovirus (PRV) is a member of the genus Orthoreovirus and family Reoviridae. Reoviridae is a large family of non-enveloped, icosahedral, segmented dsRNA viruses that infect a wide range of hosts, i.e. fungi, plants, insects, molluscs, fish, reptiles, birds and mammals, including humans [3]. Orthoreovirus, which contains 10 genome segments (three large, three medium and four small segments), consists of five

(C) The Author(s). 2018 Open Access This article is distributed under the terms of the Creative Commons Attribution 4.0 International License (http://creativecommons.org/licenses/by/4.0/), which permits unrestricted use, distribution, and 
species: mammalian orthoreovirus (MRV), avian orthoreovirus (ARV), PRV [formerly known as Nelson Bay orthoreovirus (NBV)], baboon orthoreovirus and reptilian orthoreovirus $[4,5]$. Of these, MRV is the only species that does not exert a syncytial cytopathic effect (CPE) in cell culture; therefore, it is called a non-fusogenic orthoreovirus. MRV is the prototypic orthoreovirus that causes diseases in mammals, including humans and monkeys [3]. The first isolation of PRV occurred in 1970 from a grey-headed flying fox (Pteropus poliocephalus) in Nelson Bay, Australia [6]. Its characteristics are intermediate between MRV and ARV, in which it is a fusogenic orthoreovirus that infects mammals but does not kill chicken embryos [3]. It is therefore called a mammalian fusogenic orthoreovirus. Later, other PRVs were isolated from bats and humans. Pulau virus, the second member of the NBV species group, was isolated in 1999 from pooled urine samples of the fruit bat Pteropus hypomelanus in Tioman Island, Malaysia [7]. Bat-associated Melaka and Kampar orthoreoviruses with genome sequences related to NBV were isolated in 2006 in Malaysia from patients with acute respiratory disease. The reports of these two viruses suggested the ability of PRV to cause disease in humans and evidenced its human-to-human transmission potential $[8,9]$. Subsequently, new strains of PRV were consecutively isolated from humans and bats, including patients with respiratory tract infection from Hong Kong [10, 11], Japan [12] and Malaysia [5] and bats from China $[13,14]$, Italy [15] and, most recently, the Philippines [16]. It must be noted that the infected patients from Hong Kong and Japan had histories of travel to Indonesia, and the PRV-positive bats in Italy were also imported from Indonesia. Thus far, excluding NBV, which originated from Australia, PRV has only been isolated in Southeast Asia (Malaysia, Indonesia and the Philippines) and China.

Meanwhile, mass spectrometric techniques have been increasingly utilised in virus studies. Mass spectrometry (MS), peptide mass fingerprinting and protein profiling via time-of-flight mass spectrometry (TOF MS) have been applied in studies of both human and plant viruses such as poliovirus, rhinovirus, tobacco mosaic virus and brome mosaic virus [17-19]. However, the use of peptide mass fingerprinting to identify unknown viruses is restricted by limitations of viral peptide mass fingerprint databases and the capability of TOF MS to identify small amounts of viral peptides when disturbed by mammalian proteins from cell culture. To overcome these limitations, protein separation techniques such as gel electrophoresis and liquid chromatography (LC) in combination with MS are applied. MS, in particular tandem MS (MS/MS), is a sensitive method for analysing protein mixtures [20]. Two-dimensional (2D) electrophoresis in combination with high-performance liquid chromatography-tandem mass spectrometry (HPLC-MS/MS) was used to identify an uncharacterised virus in an experimentally infected tobacco plant protein extract [21].

The initial aim of this study was to survey for the presence of hepatitis E virus (HEV) in monkey faeces. HEV is a food- and water-borne, non-enveloped, positive-sense RNA virus of the Hepeviridae family. The virus causes diseases ranging from acute self-limiting illnesses to fulminant hepatitis in humans [22]. In Thailand, sporadic cases of HEV infection have been reported. Nationwide HEV sero-surveillance revealed an HEV seroprevalence rate of $3-26 \%$ in Thai provinces [23]. Focussing on Lopburi Province, $37 \%$ of people in a surveyed population were anti-HEV IgG positive, with positivity associated with pork consumption and the presence of swine farms in the area [24]. HEV is the only hepatitis virus that exhibits a zoonotic potential, with pigs as a primary reservoir [22]. In addition, HEV has been detected in wild boars, wild deer, mongooses, rabbits, rats and goats in various countries in Asia and Europe [22, 25, 26]. Non-human primates (NHPs) have been demonstrated to be experimentally infected by HEV and to secrete the virus. Although it has been suggested that monkeys serve as an asymptomatic reservoir of HEV [27], the prevalence of HEV in wild monkeys in Thailand has not yet been elucidated.

In this study, we report the first isolation and characterisation of an orthoreovirus from monkey faeces collected from areas occupied by humans in Lopburi Province, Thailand. Two virus isolates were retrieved via viral culture. These isolates named Lopburi01 and Lopburi02 were identified using SDS-PAGE, LC-MS/MS and protein database searches, and their genomes were characterised by phylogenetic analysis. In addition, the detection of PRV and HEV by RT-PCR in all monkey samples was reported.

\section{Results \\ Isolation of Lopburi01 and Lopburi02 viruses from monkey faeces}

Of 55 monkey faecal samples, 2 virus isolates were retrieved by virus culture in A549 cells. After virus culturing for 3 days, CPEs were observed in samples collected from sites 1 (temple area) and 5 (working area) (Fig. 1 and Table 1). Culture supernatants were harvested and sub-passaged in A549 and Vero cells. CPEs observed in both cell types infected with the two isolates exhibited the same characteristic, syncytium formation (Fig. 2a). The virus isolates were named Lopburi01 and Lopburi02, respectively. Growth kinetics of the viruses in A549 and Vero cells were investigated (Fig. 2b). The Lopburi viruses showed a higher degree of replication in A549 cells than in Vero cells. RNA extracted from the 


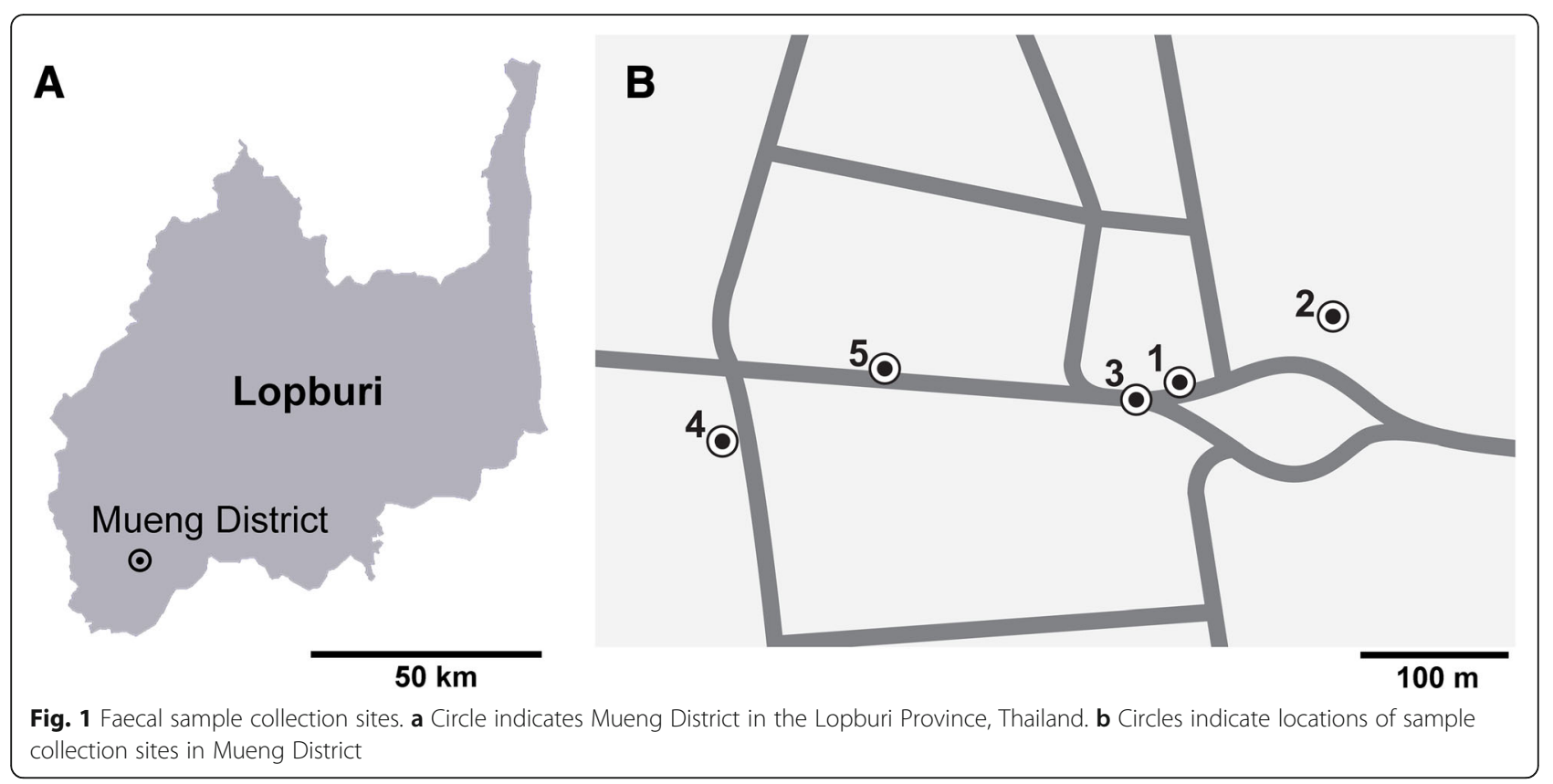

culture supernatants of Lopburi01 and Lopburi02 were tested for HEV, herpesvirus, enterovirus, rotavirus, enteric adenovirus, norovirus and astrovirus, but negative results were obtained.

\section{Physicochemical and morphological properties of the isolated viruses}

To further characterise the Lopburi01 and Lopburi02 viruses, their stabilities under temperature, chloroform and acid stress were compared with those of untreated controls. As shown in Fig. 3, the Lopburi02 virus resisted exposure to temperatures up to $50{ }^{\circ} \mathrm{C}$, whereas it was destroyed by exposure to temperatures exceeding $60{ }^{\circ} \mathrm{C}$ for $1 \mathrm{~h}$. Treatment with chloroform for 30 and $60 \mathrm{~min}$ did not inactivate the virus, although a slight decrease in $\mathrm{TCID}_{50}$ was observed compared with that of the untreated virus $(0 \mathrm{~min})$. The virus was not inactivated by exposure to $\mathrm{pH} 3$ or $\mathrm{pH} 5$ for $20 \mathrm{~h}$. Moreover, an approximately $1 \log _{10}$ increase in $\mathrm{TCID}_{50} / \mathrm{mL}$ was observed when the virus was exposed to

Table 1 Details of the monkey faecal sample collection, virus isolation and virus detections

\begin{tabular}{lllllll}
\hline \multicolumn{2}{l}{ Sample collection } & & & & \multicolumn{2}{l}{ Nested RT-PCR } \\
\cline { 1 - 1 } Site & Place & Number & Virus isolation & PRV positive & HEV positive \\
\hline 1 & Temple area & 13 & 1 & $1(7.7 \%)$ & $3(23.1 \%)$ \\
2 & School area & 4 & 0 & $1(25 \%)$ & $1(25 \%)$ \\
3 & Temple area & 14 & 0 & $3(21.4 \%)$ & $6(42.9 \%)$ \\
4 & House area & 12 & 0 & 0 & $1(8.3 \%)$ \\
5 & Working area & 12 & 1 & $1(8.3 \%)$ & $3(25 \%)$ \\
& Total & 55 & 2 & $6(10.9 \%)$ & $14(25.5 \%)$ \\
\hline
\end{tabular}

acidic treatment ( $\mathrm{pH} 3$ and $\mathrm{pH}$ 5) compared with the effects of PBS ( $\mathrm{pH} 7$ ). The same results were observed with the Lopburi01 isolate. Taken together, the results suggested that Lopburi01 and Lopburi02 are non-enveloped viruses that resist chloroform and acidic $\mathrm{pH}$.

Transmission electron microscopy was used to determine the morphology of Lopburi02 in Vero cell pellets. Non-enveloped virus particles of $50-80 \mathrm{~nm}$ in size with an icosahedral structure were observed in the Vero cell cytoplasm (Fig. 4).

\section{Identification of the Lopburi virus by LC-MS/MS}

To further identify the unknown viruses, the Lopburi02 virus was propagated, and proteins were extracted from the concentrated virus. The whole protein lysate, composed of host and viral proteins (Fig. 5), was analysed via gel-based LC-MS/MS. After searching the NCBI protein database using the Mascot program focussing on viral proteins, it was suggested that Lopburi02 is an orthoreovirus (Table 2). The top five protein hits were matched to structural and non-structural proteins of PRV, Melaka, Pulau and Sikamat orthoreoviruses. After obtaining the LC-MS/MS result, primers (Additional file 1: Table S1) were designed on the basis of the S1 genomic sequence of the Melaka orthoreovirus. The primers were used in RT-PCR with RNA extracted from the culture supernatants of the Lopburi01 and Lopburi02, and results showed that both viruses are PRV.

\section{Whole-genome analysis of the Lopburi orthoreoviruses}

Sets of overlapping primers were designed on the basis of the genome sequences of the Melaka orthoreovirus 


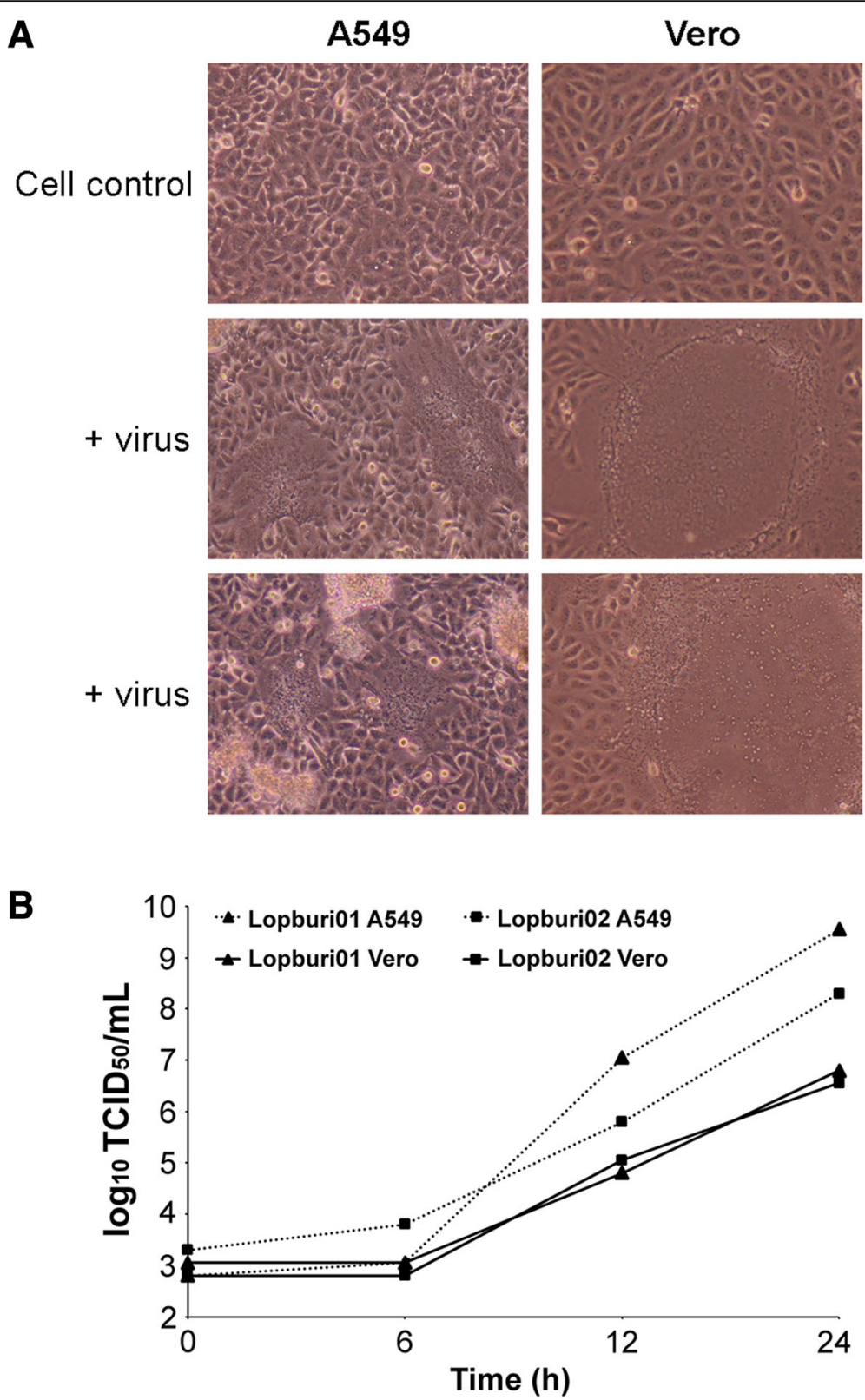

Fig. 2 Cytopathic effect (CPE) and growth kinetics of the Lopburi viruses in A549 and Vero cells. a The cells were inoculated with the virus (Lopburi02) for $24 \mathrm{~h}$. A syncytial CPE was observed in both infected Vero and A549 cell monolayers but not in uninfected cells. Similar data were obtained for the Lopburi01 isolate. b A549 and Vero cells were infected with the Lopburi01 and Lopburi02 viruses at MOI of 0.5 for $24 \mathrm{~h}$. Viral growth curves were obtained by titration of the virus culture supernatants collected at 0, 6, 12, and $24 \mathrm{~h}$. The result is a representative of 2 independent experiments

(Additional file 1: Table S1) to amplify all 10 genome segments of the Lopburi01 and Lopburi02 viruses for nucleotide sequencing. After sequence analysis via nucleotide sequence alignment and contig assembly, all 10 whole-genome segment sequences of the Lopburi01 and Lopburi02 viruses were retrieved and submitted to the NCBI GenBank database. Table 3 shows the GenBank accession numbers and percent nucleotide and protein sequence identities of the two newly isolated viruses. Lopburi01 and Lopburi02 are identical with nucleotide and protein sequence identities of $99.7-100 \%$. The nucleotide sequences of all segments were subjected to BLAST searches using the NCBI database. Published nucleotide sequences that exhibited the highest percent identities to sequences of the isolated virus are presented in Table 4. The identities with the reference sequences were $93.5-98.9 \%$ in all 10 segments. Re-assortments within the species group were observed in the Lopburi orthoreovirus genome. Segment L1 of the Lopburi virus is most identical to that of the bat-origin Pulau 


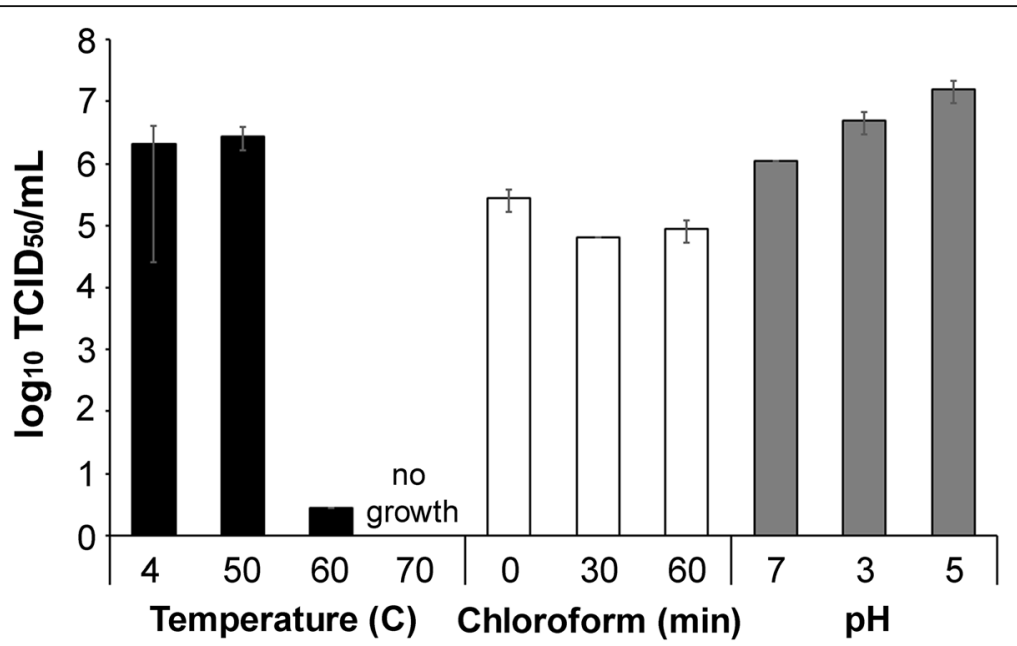

Fig. 3 Physicochemical properties of the Lopburi virus. Culture supernatants of the Lopburi02 virus were exposed to different temperatures for $1 \mathrm{~h}$ (black bars), chloroform for 30 or $60 \mathrm{~min}$ (white bars) and different pH conditions for $20 \mathrm{~h}$ (grey bars). After treatment, the viruses were titrated in Vero cells, and their levels were quantified as $\mathrm{TCID}_{5} / \mathrm{mL}$. Two independent experiments were performed for each assay. Similar findings were observed for the Lopburi01 isolate

orthoreovirus of Malaysia. Segments L2, M3 and S3 are closely related to those of the bat-origin Cangyuan orthoreovirus of China. Segments L3 and M2 are related to those of the human-origin Melaka orthoreovirus of Malaysia. Segments M1 and S2 are closely related to those of the human-origin Kampar orthoreovirus of Malaysia. Segments S1 and S4 are closely related to those of the human-origin Sikamat orthoreovirus of Malaysia.

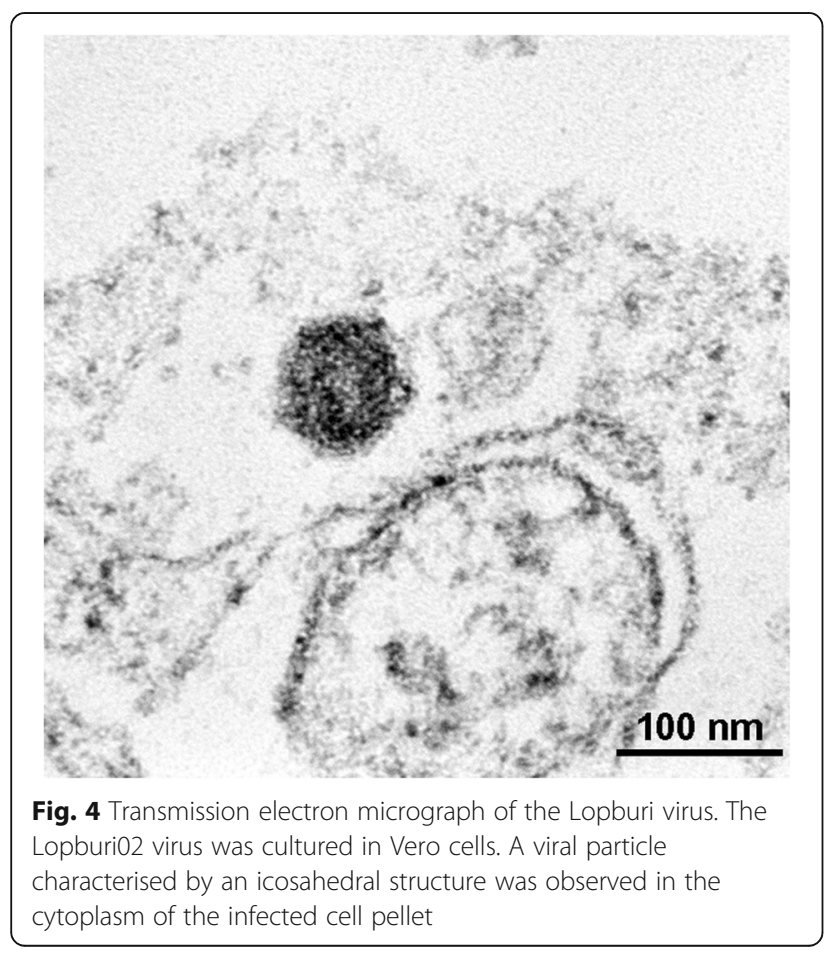

Phylogenetic trees constructed using the maximum likelihood method are shown in Fig. 6 (L1, L2 and L3), Fig. 7 (M1, M2 and M3) and Fig. 8 (S1, S2, S3 and S4). The completed nucleotide sequences of the Lopburi01 and Lopburi02 viruses were compared with those of other PRV retrieved from the public database. Phylogenetic tree analysis demonstrated that the Lopburi orthoreoviruses are closely related to the Cangyuan, Melaka, Kampar and Sikamat orthoreoviruses that were identified in 2006-2012 in China and Malaysia. The newly identified Lopburi viruses most strongly resemble the Cangyuan virus with five segments (L1, L2, M3, S3 and S4) clustered together. The viruses are relatively separated from the prototype Nelson Bay orthoreovirus and the recently described Samal and Talikud PRVs from the Philippines.

Considering the nucleotide and protein sequence identities among the PRV sequences subjected to analysis, Table 5 presents the percent identities for each genome segment. The most conserved genome segment was S2 encoding a major inner capsid protein (96.3-100\% amino acid identity). The most variable genome segment was $\mathrm{S} 1$, which contains three coding regions, p10 (membrane fusion protein), p17 and sigma C (cell attachment protein). The nucleotide sequence identities for these regions were $65.9-100 \%$, $54.7-100 \%$ and $47.6-100 \%$, respectively, and the amino acid sequence identities were $69.4-100 \%, 44.5-$ $100 \%$ and $36.4-100 \%$, respectively. Table 5 also presents percent sequence identities of each genome segment of the Lopburi viruses compared with those of the 5 closely related orthoreoviruses Pulau, Cangyuan, Melaka, Kampar and Sikamat orthoreoviruses. 


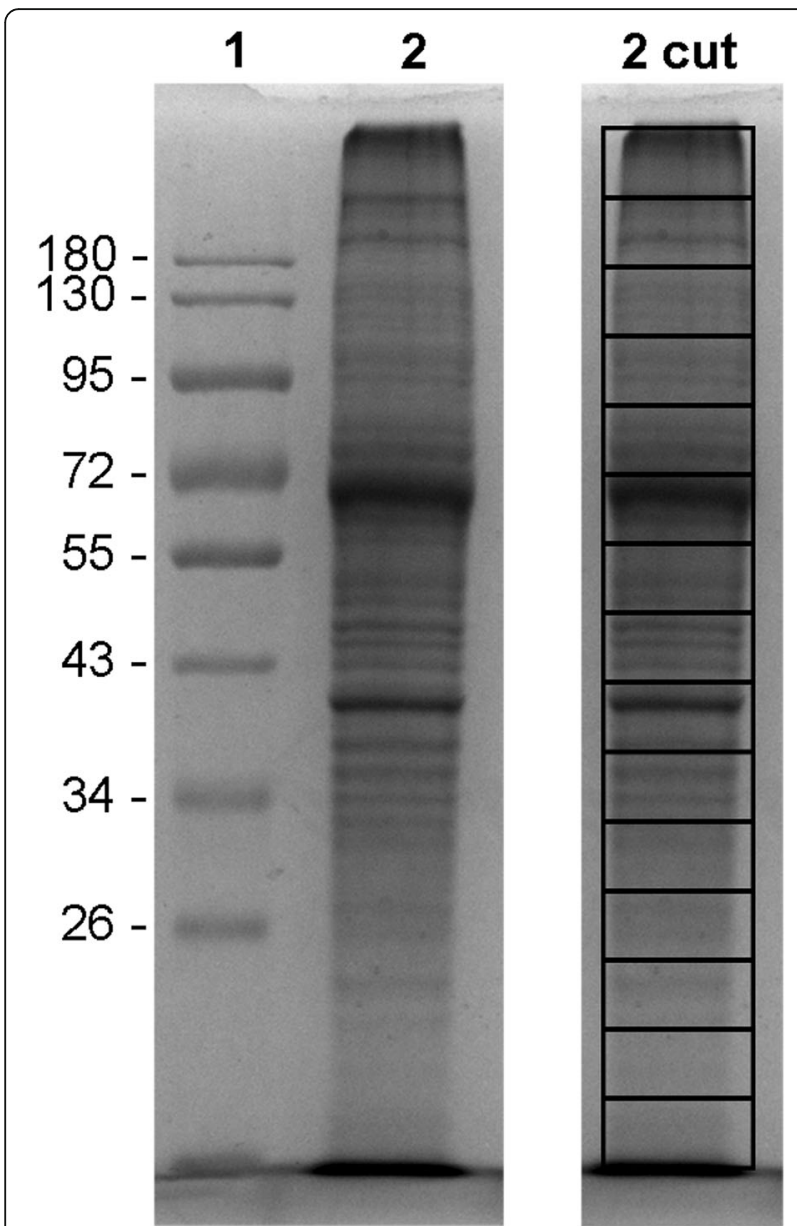

Fig. 5 SDS-PAGE of the Lopburi virus protein lysate. The Lopburi02 virus cultured in Vero cells was concentrated by ultracentrifugation, lysed by lysis buffer containing SDS and resolved by SDS-PAGE (lane 2). The gel was cut along its length into 15 pieces for mass spectrometric analysis (lane 2 cut). PageRuler protein marker (Thermo Scientific) was used as a protein size marker (lane 1)

Detection of PRV and HEV RNA in monkey faecal samples and monkey species identification

Semi-nested RT-PCR was used to detect PRV and HEV RNA in the 55 faecal samples. Six samples $(10.9 \%)$ were PRV positive according to the RT-PCR targeting PRV S1 segment. Fourteen samples (25.5\%) were HEV positive according to the semi-nested RT-PCR targeting HEV ORF1 (Table 1). HEV-positive samples were detected from all five sampling sites, whereas PRV-positive samples were detected from four sites. Sequencing and BLAST analysis of the nested PCR products confirmed the detection of PRV and HEV sequences from monkey faeces.

PCR of mitochondrial 12S rRNA gene was used to confirm the monkey species in all PRV- and HEV-positive samples. The results of nucleotide sequencing and BLAST search revealed that the monkey species of all PRV- and HEV-positive samples is Macaca fascicularis.

\section{Discussion}

In Lopburi Province, Thailand, macaques live in close proximity to human communities, including temples, schools, houses and working areas. Despite efforts to avoid close contact with animals, the potential for contact with animal faeces excreted into the environment remains. Four species of macaques reside in Lopburi Province, long-tailed or cynomolgus macaques (Macaca fascicularis), rhesus macaques (Macaca mulatta), pig-tailed macaques (Macaca nemestrina) and stump-tailed macaques (Macaca arctoides), with long-tailed macaques being a major species. In this study, two unknown viruses were isolated from monkey faeces. The isolates demonstrated a syncytial CPE on A549 and Vero cells. Primers specific for viruses possibly found in monkey fluids and faeces such as herpesviruses and enteric viruses, including enterovirus, norovirus, rotavirus, enteric adenovirus and astrovirus, were used in PCR and RT-PCR for the isolated viruses, but negative results were obtained. Subsequently, mass spectrometry was applied, and the viruses were successfully identified as PRVs named Lopburi01 and Lopburi02. Previously, 2D gel electrophoresis for protein separation and HPLC-MS/MS was used to identify an unknown virus from a plant extract [21]. In this study, we demonstrated that a simple SDS-PAGE for protein size separation followed by LC-MS/MS of trypsin-digested peptides and protein database searching can also be used to identify unknown culturable viruses. Furthermore, on performing RT-PCR for all monkey samples available, PRV was detected in 10.9\% (6 of 55) of the faecal samples collected from different sites in the Mueng District of Lopburi Province. The analysis of the mitochondrial $12 \mathrm{~S}$ rRNA gene in the monkey stool DNA confirmed

Table 2 Top 5 of the Lopburi02 viral proteins analysed by LC-MS/MS and Mascot program

\begin{tabular}{llll}
\hline No. & Protein accession no. & Description & Organisms \\
\hline 1 & gi|459014590 & Major outer capsid (M2) & Melaka orthoreovirus \\
2 & gi|38194450 & Non-structural protein sigma NS (S3) & Pulau reovirus \\
3 & gi|355477204 & Sigma 2 (S4) & Pulau reovirus \\
4 & gi|38194452 & Major outer capsid protein sigma 2 (S4) & Melaka orthoreovirus \\
\hline
\end{tabular}


Table 3 Accession numbers of 2 newly identified orthoreovirus isolates and their \% sequence identities in coding regions

\begin{tabular}{lllllllllll}
\hline & L1 & L2 & L3 & M1 & M2 & M3 & S1 & S2 & S3 & S4 \\
\hline Lopburi01 & KY751007 & KY751009 & KY751011 & KY751013 & KY751015 & KY751017 & KY751019 & KY751021 & KY751023 & KY751025 \\
Lopburi02 & KY751008 & KY751010 & KY751012 & KY751014 & KY751016 & KY751018 & KY751020 & KY751022 & KY751024 & KY751026 \\
a\% identity & 99.9 & 100 & 99.8 & 99.9 & 99.7 & 100 & 100 & 100 & 100 & 99.8 \\
b\% identity & 99.9 & 100 & 99.7 & 99.7 & 100 & 100 & 100 & 100 & 100 & 99.7 \\
\hline
\end{tabular}

a identity of nucleotide sequences

$\mathrm{b}_{\%}$ identity of translated protein sequences

that the host species from which the Lopburi orthoreoviruses were isolated was $M$. fascicularis.

The identification of the Lopburi orthoreoviruses by MS was in agreement with the physicochemical properties and morphological characteristic of the viruses observed by other assays. The isolates were identified as non-enveloped viruses that exert syncytial CPEs on A549 and Vero cells, which is a characteristic of PRVs [3]. The viruses are resistant to chloroform, which is characteristic of non-enveloped viruses, and acidic conditions, facilitating their persistence in faeces [4]. Incubation at $\mathrm{pH} 3$ and $\mathrm{pH} 5$ promoted the growth of the virus, as indicated by increases of $\log _{10} \mathrm{TCID}_{50}$ compared with that observed in the control.

This study marks the first detection of an orthoreovirus in monkey faeces from Thailand. Phylogenetic analysis of the isolates indicated that Lopburi01 and Lopburi02 are the same virus with sequence identities of $\geq 99.7 \%$ in all genome segments. Of the 10 segments of orthoreovirus genomes, all but S1 contain one ORF encoding a structural or non-structural protein. S1 is polycistronic, as it can encode $1-3$ proteins depending on the orthoreovirus species [3]. S1 of PRV is tricistronic with three overlapping ORFs, and it encodes p10 (membrane fusion protein), p17 and sigma C (cell attachment protein). Among these segments, S1 exhibits the greatest variability $[14,16]$. In our analysis, the nucleotide and amino acid sequence identities were $47.6 \%$ and $36.4 \%$, respectively. Furthermore, considering differences in the topology patterns of the phylogenetic trees, it can be suggested that genetic re-assortment occurred among orthoreovirus species. The Lopburi orthoreoviruses contain genome sequences related to those of the Pulau (L1), Kampar (M1 and S2), Melaka (L3 and M2) and Sikamat (S1 and S4) viruses of Malaysia and the Cangyuan virus (L2, M3 and S3) of South China with sequence identities of 93.5-98.9\%. It can be speculated that a geographical hindrance may have played a role in the re-assortment, as the orthoreovirus from Thailand is more similar to viruses from Malaysia and China than to those from the Philippines (Samal and Talikud viruses), which is separated from Thailand by the Pacific Ocean.

As the Lopburi viruses were isolated from monkey faeces collected from the ground, the impact of the viruses on the animals' health could not be demonstrated. Their role in human diseases also requires further investigation. Recently, a report illustrated the detection of PRV nucleic

Table 4 Highest nucleotide identities for each gene segment of the Lopburi02 orthoreovirus retrieved from the BLAST search

\begin{tabular}{|c|c|c|c|c|c|c|c|}
\hline Segment & Encoded protein & $\%$ identity & Ref. strain & Host & Country & Year & Acc. no. \\
\hline \multirow[t]{2}{*}{ L1 } & \multirow[t]{2}{*}{$\lambda C$ or $\lambda 3$} & 93.5 & Pulau & Bat & Malaysia & 1999 & JF342666.1 \\
\hline & & 92.9 & Cangyuan & Bat & China & 2012 & KM382259.1 \\
\hline L2 & $\lambda B$ or $\lambda 2$ (RNA pol) & 98.2 & Cangyuan & Bat & China & 2012 & KM382260.1 \\
\hline L3 & $\lambda A$ or $\lambda 1$ & 97.9 & Melaka & Human & Malaysia & 2006 & JF342662.1 \\
\hline \multirow[t]{2}{*}{ M1 } & \multirow[t]{2}{*}{$\mu \mathrm{A}$ or $\mu 1$} & 96.2 & Kampar & Human & Malaysia & 2006 & $J F 342657.1$ \\
\hline & & 95.8 & Melaka & Human & Malaysia & 2006 & JF342663.1 \\
\hline M2 & $\mu \mathrm{B}$ or $\mu 2$ & 95.8 & Melaka & Human & Malaysia & 2006 & $J F 342664.1$ \\
\hline M3 & $\mu N S$ & 98.9 & Cangyuan & Bat & China & 2012 & KM382264.1 \\
\hline S1 & $\mathrm{p} 10, \mathrm{p} 17$ and $\sigma \mathrm{C}$ & 95.5 & Sikamat & Human & Malaysia & 2010 & JF811580.1 \\
\hline S2 & $\sigma A$ or $\sigma 1$ & 98.7 & Kampar & Human & Malaysia & 2006 & EU448335.1 \\
\hline \multirow[t]{2}{*}{ S3 } & \multirow[t]{2}{*}{$\sigma N S$} & 97.7 & Cangyuan & Bat & China & 2012 & KM382267.1 \\
\hline & & 97.7 & Xi river & Bat & China & 2010 & GU188275.1 \\
\hline \multirow[t]{2}{*}{ S4 } & \multirow[t]{2}{*}{$\sigma B$ or $\sigma 2$} & 97.2 & Sikamat & Human & Malaysia & 2010 & JF811583.1 \\
\hline & & 96.7 & Cangyuan & Bat & China & 2012 & KM382268.1 \\
\hline
\end{tabular}

$L$ large segment, $M$ medium segment, $S$ small segment 

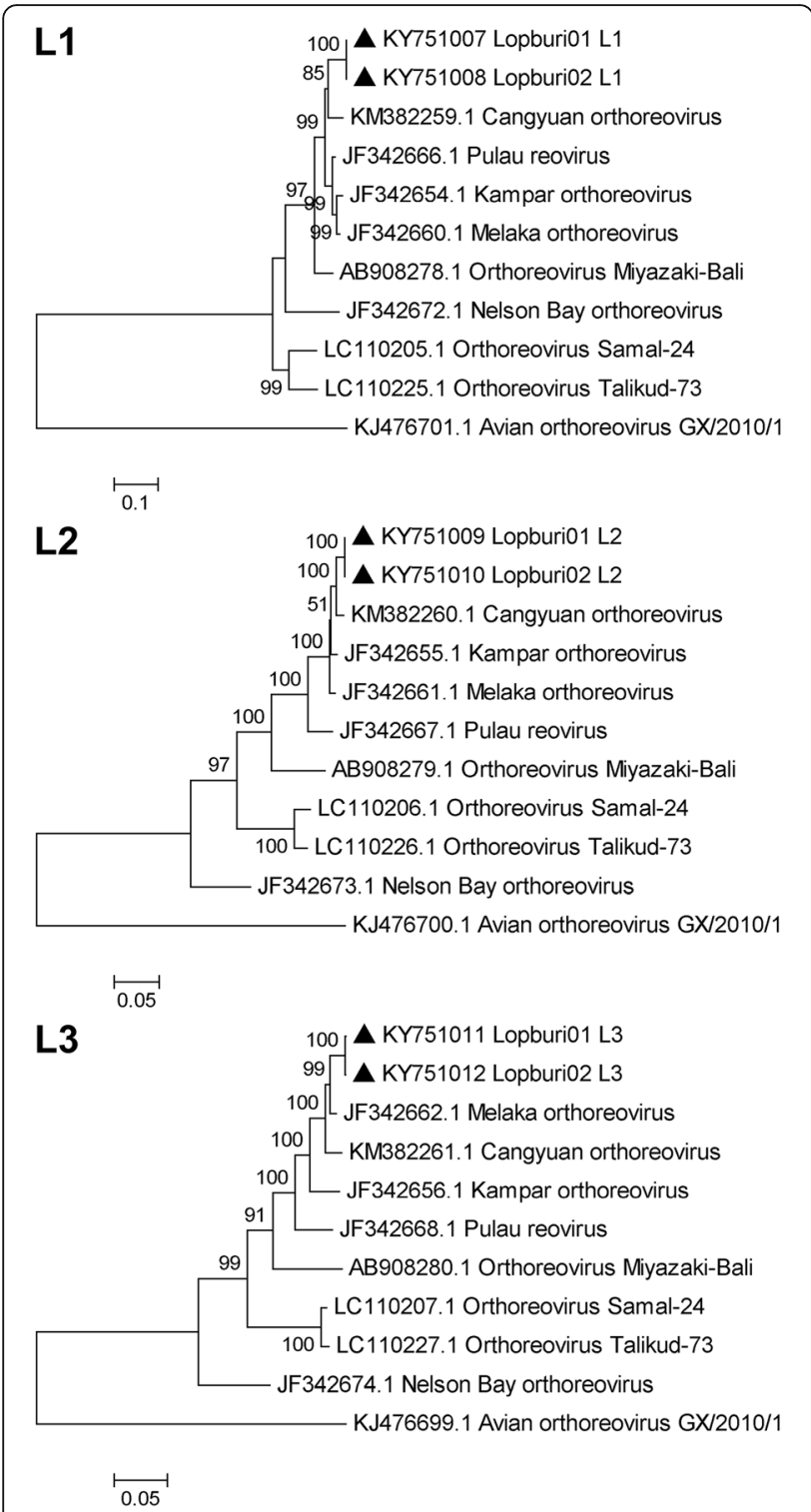

Fig. 6 Phylogenetic trees based on nucleotide sequences of the whole $L$ segments ( $L 1-L 3$ ) of pteropine orthoreovirus. Phylogenetic trees were constructed using the maximum likelihood method and 1000 bootstrap replicates. Virus names and nucleotide sequence accession numbers obtained in this study are marked with triangles. The scale bar represents the number of nucleotide substitutions per site. Bootstrap values greater than 50 are indicated at the nodes. Sequences of the avian orthoreovirus GX/2010/1 were used as outgroups

acids in $17 \%$ of oropharyngeal swabs collected from outpatients in Malaysia with acute upper respiratory tract infection. The viral agents were related to the Melaka and Kampar orthoreoviruses [28]. A sero-survey in Central Vietnam demonstrated that $4.4 \%$ of serum samples were PRV IgG positive [29]. These data were important because Vietnam shares a border with China. These findings emphasise that PRV is a bat-borne zoonotic virus that has high potential to cause cross-species infection in humans.

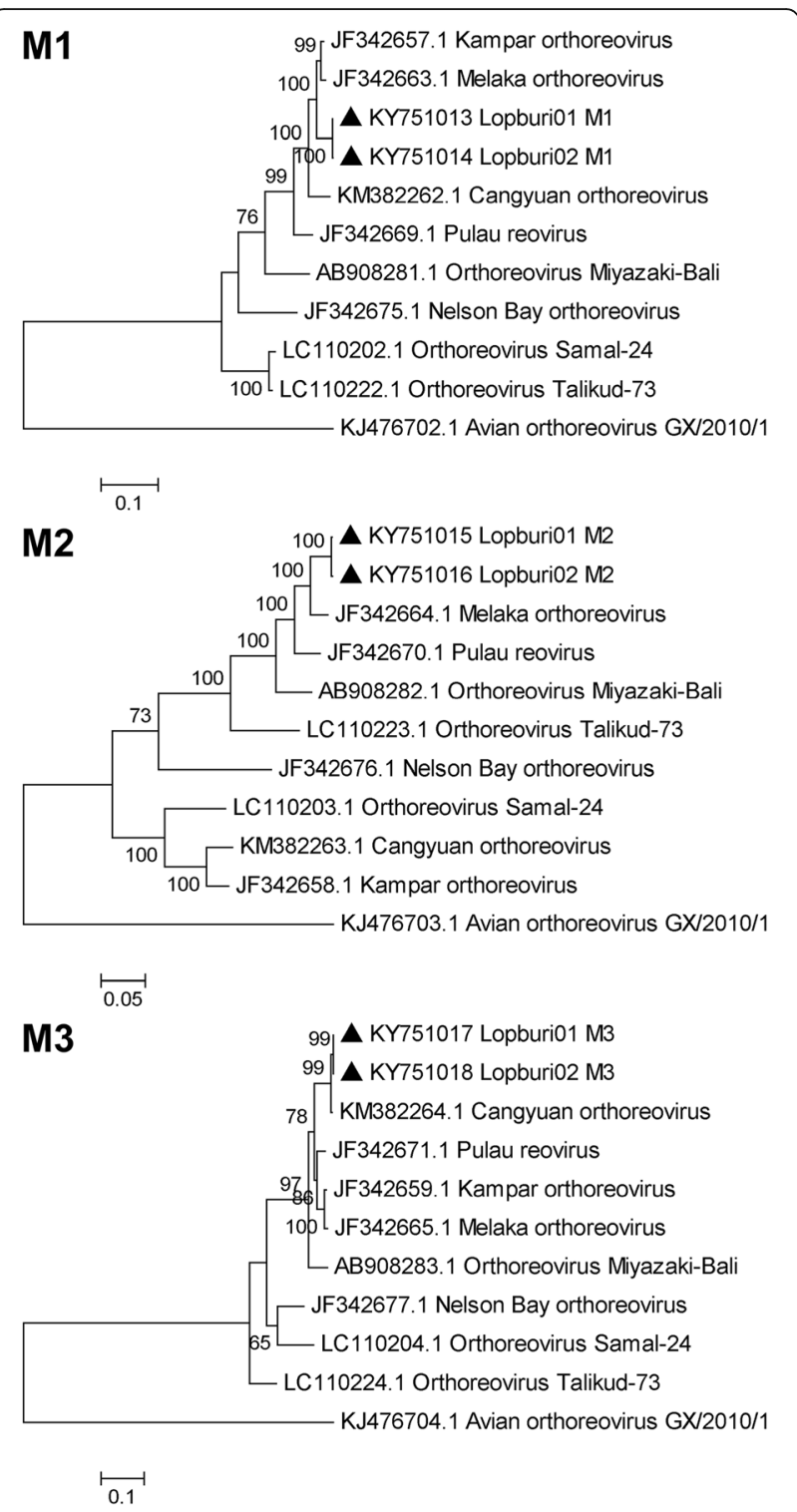

Fig. 7 Phylogenetic trees based on nucleotide sequences of the whole M segments (M1-M3) of pteropine orthoreovirus. Phylogenetic trees were constructed using the maximum likelihood method and 1000 bootstrap replicates. Virus names and nucleotide sequence accession numbers obtained in this study are marked with triangles. The scale bar represents the number of nucleotide substitutions per site. Bootstrap values greater than 50 are indicated at the nodes. Sequences of the avian orthoreovirus GX/2010/1 were used as outgroups

Another important issue is the possibility of monkey faeces contamination by PRV-positive bat excreta before the time of sample collection. Thailand is home to 139 different bat species, including fruit bats and flying foxes of the genera Pteropus, Rousettus and Eonycteris [30, 31], from which PRVs were isolated [6, 7, 13-16]. Fruit bats visit human areas to feed on fruit trees; in this case, the areas occupied by humans, monkeys and bats may overlap. In addition to PRV, the bats were infected with other 

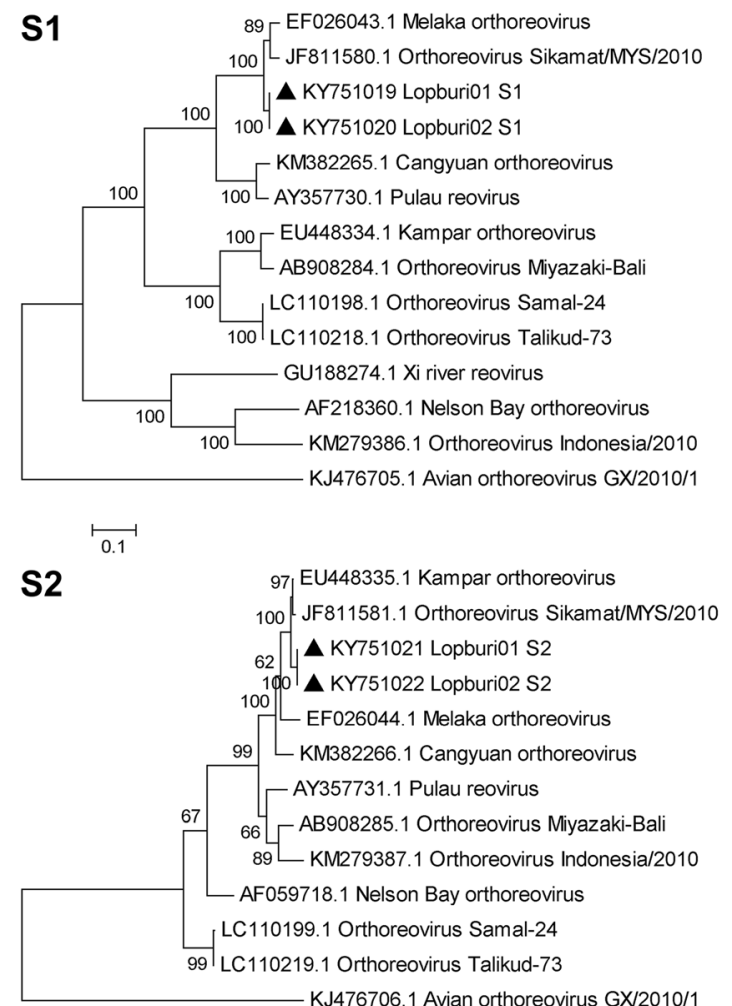

KJ476706.1 Avian orthoreovirus GX/2010/1
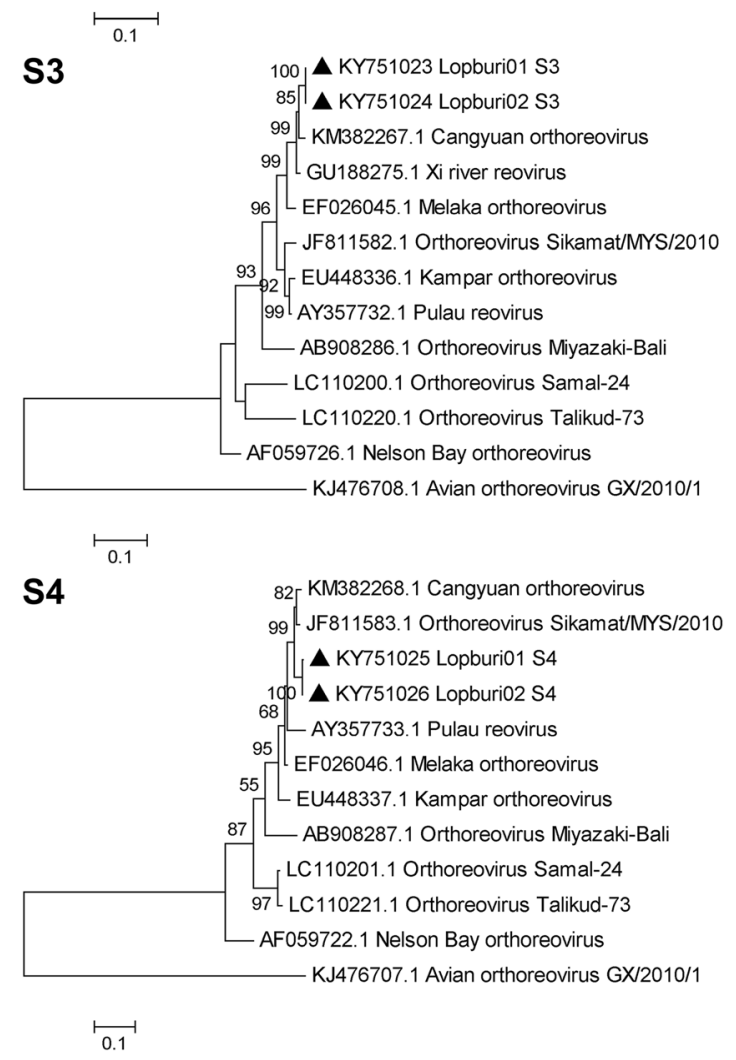

Fig. 8 Phylogenetic trees based on nucleotide sequences of the whole S segments (S1-S4) of pteropine orthoreovirus. Phylogenetic trees were constructed using the maximum likelihood method and 1000 bootstrap replicates. Virus names and nucleotide sequence accession numbers obtained in this study are marked with triangles. The scale bar represents the number of nucleotide substitutions per site. Bootstrap values greater than 50 are indicated at the nodes. Sequences of the avian orthoreovirus GX/2010/1 were used as outgroups

viruses such as coronaviruses and the Nipah virus $[30,31]$. Therefore, even if the detection of PRV in monkey faeces was due to contamination by bat excreta, the possibility of monkey faeces as an indirect source of zoonotic diseases cannot be eliminated. However, by analysis of the mitochondrial $12 \mathrm{~S}$ rRNA gene, bat DNA was not detected in the faecal samples in this study, thus ruling out the contamination of the monkey samples with bat faeces.

Besides the detection of PRV by virus culture and RT-PCR, this particular set of monkey samples was originally intended for HEV detection. It was reported that NHPs such as macaques and chimpanzees can be experimentally infected by four serotypes of HEV, serotypes 1 and 2 found in humans and serotypes 3 and 4 found in humans and swine [32, 33]. A productive infection with seroconversion and viral shedding in faeces was demonstrated in cynomolgus macaques without clinical symptoms, indicating that the infected NHPs can serve as asymptomatic carriers of HEV [27]. In total, $25 \%$ of the faecal samples collected in this study were HEV RNA-positive, suggesting that monkeys in the wild could be reservoirs for HEV. Unfortunately, the HEV genotypes could not be identified because the short RT-PCR product ( $85 \mathrm{bp}$ ) was not suitable for genotype analysis. However, the detection of HEV RNA with a high detection rate in monkey faeces, even higher than that reported in pigs, the primary reservoir [34-36], can be used as a preliminary information that warrants a further investigation to conclude that monkey faeces are a source of HEV.

\section{Conclusions}

We have detected and isolated PRV in M. fascicularis faeces collected from human areas in Thailand. The usefulness of the gel-based LC-MS/MS technique for identifying unknown culturable viruses was demonstrated. Whole-genome characterisation of the new PRV, the Lopburi orthoreovirus, was described. In addition, HEV RNA was detected in monkey faeces. Our results emphasise monkeys, especially a long-tailed macaque, as potential reservoirs of zoonotic viruses, such as PRV and possibly $\mathrm{HEV}$, and suggest the need for systemic surveys of zoonotic viruses, especially in areas where human and animal habitats overlap. 
Table 5 Ranges of \% nucleotide and translated protein sequence identities compared between PRV sequences used for the phylogenetic analysis and between Lopburi viruses and 5 most closely related strains

\begin{tabular}{|c|c|c|c|c|c|c|c|c|c|c|c|c|}
\hline \multirow[t]{2}{*}{ Segment } & \multicolumn{6}{|c|}{$\%$ nucleotide identity } & \multicolumn{6}{|c|}{$\%$ amino acid identity } \\
\hline & All strains & Pulau & Kampar & Melaka & Sikamat & Cangyuan & All strains & Pulau & Kampar & Melaka & Sikamat & Cangyuan \\
\hline L1 & $80.6-99.9$ & $93.4-93.5$ & 92.3 & 92.7 & - & 92.9 & $91.1-99.9$ & $97.7-97.8$ & 97.5 & $97.1-97.2$ & - & $97.7-97.8$ \\
\hline L2 & $83.2-100$ & 94 & 97.8 & 97.7 & - & 98.2 & $95.5-100$ & 98.6 & 99.2 & 99.2 & - & 99.6 \\
\hline L3 & $84.0-99.8$ & $92.6-92.7$ & $94.2-94.3$ & 97.9 & - & 96.7 & $96.1-99.7$ & $98.4-98.5$ & $98.8-98.9$ & 99.3 & - & 99.3 \\
\hline M1 & $81.5-99.9$ & $91-91.1$ & $96.1-96.2$ & 95.8 & - & $92.6-92.7$ & $92.0-99.7$ & $96.5-96.8$ & $98.3-98.6$ & $98.6-98.9$ & - & $97.8-98$ \\
\hline M2 & 77.6-99.7 & $93.3-93.4$ & $78.1-78.2$ & $95.6-95.7$ & - & 78.5 & $93.6-100$ & 99.7 & 94.9 & 100 & - & 95.1 \\
\hline M3 & $81.1-100$ & 93.5 & 93.4 & 93 & - & 98.9 & $90.3-100$ & 98.2 & 98.4 & 97.9 & - & 99.3 \\
\hline S1 p10 & $65.9-100$ & 88.8 & 82.6 & 97.5 & 96.5 & 87.1 & 69.4-100 & 98.9 & 93.6 & 100 & 98.9 & 98.9 \\
\hline S1 p17 & $54.7-100$ & 86.9 & 75.5 & 97.4 & 97.4 & 87.8 & $44.5-100$ & 91.6 & 82.5 & 96.5 & 96.5 & 90.9 \\
\hline S1 oC & $47.6-100$ & 76.4 & 57.3 & 94.6 & 93.8 & 76.3 & $36.4-100$ & 78.4 & 55.4 & 95.4 & 93.9 & 79 \\
\hline S2 & $82.8-100$ & 91.4 & 98.6 & 94.7 & 98.3 & 94.6 & $96.3-100$ & 98.3 & 99.7 & 99.2 & 99.5 & 98.5 \\
\hline S3 & $84.1-100$ & 93 & 92.3 & 95.4 & 92.3 & 97.6 & $93.7-100$ & 98.9 & 98.6 & 99.7 & 99.1 & 98.9 \\
\hline S4 & 81.3-99.8 & $92.1-92.3$ & 91.9 & $95-95.2$ & $96.8-97$ & $96.3-96.5$ & 88.6-99.7 & 92.7-93 & $96.3-96.6$ & $98-98.3$ & 98.8-99.1 & $99.1-99.4$ \\
\hline
\end{tabular}

\section{Methods}

\section{Faecal samples}

Fifty-five monkey faecal samples were collected in 2013 from the ground in five sites in Mueng District, Lopburi Province, Thailand (Fig. 1 and Table 1). The identities of the monkey faeces were provisionally confirmed by veterinarians according to their appearance. Monkeys found in the sample collection areas were macaques (Macaca spp.). No contact with the animals occurred during the collection process. The samples were transferred on ice and stored at $-80{ }^{\circ} \mathrm{C}$ until further processing. Faeces were processed by adding phosphate-buffered saline (PBS, $\mathrm{pH} 7.2)$ to produce $30 \%(w / v)$ solutions, which were mixed by vortexing and sonicated for $10 \mathrm{~min}$ at $4^{\circ}$ $\mathrm{C}$ before centrifugation at $1000 \times \mathrm{g}$ for $15 \mathrm{~min}$ at $4{ }^{\circ} \mathrm{C}$. Supernatants were collected and stored at $-80^{\circ} \mathrm{C}$.

\section{Virus isolation in A549 cell}

Virus isolation was performed in the human lung epithelial cell line A549 (ATCC CCL-185). Supernatants of the $30 \%$ faecal suspension (w/v) in PBS were filtered through $0.45-\mu \mathrm{m}$ syringe filters after debris removal by centrifugation at $1000 \times g$ for $15 \mathrm{~min}$ at $4{ }^{\circ} \mathrm{C}$. One hundred microlitres of the filtrates were added to the A549 cell monolayers (80-90\% confluent) grown in a 24 -well tissue culture plate and incubated at $37{ }^{\circ} \mathrm{C}$ in a $5 \% \mathrm{CO}_{2}$ atmosphere for $1 \mathrm{~h}$. The inocula were discarded, and the cells were washed with PBS prior to the addition of minimum essential medium (MEM) supplemented with $2 \%$ foetal bovine serum (FBS), penicillin-streptomycin solution and insulin-transferrin-selenium-ethanolamine (ITS-X) (Gibco, Thermo Fisher Scientific), the latter of which was added according to a method for HEV isolation [37]. The cells were incubated at $37{ }^{\circ} \mathrm{C}$ in a $5 \% \mathrm{CO}_{2}$ atmosphere and observed daily for 5 days for the presence of CPE and compared with the observations in control cells. Two sub-passages were performed before the cultures were discarded. Supernatants from CPE-positive samples were collected and stored at $-80^{\circ}$ $\mathrm{C}$ for further analysis.

\section{Virus propagation in Vero cell}

Virus propagation was performed in African green monkey kidney cells (Vero) (ATCC CCL-81), which are regularly used in our laboratory. The CPE-positive culture supernatants were diluted (1:10) in Dulbecco's modified Eagle's medium (DMEM) supplemented with $2 \%$ FBS and penicillin-streptomycin solution (2\% FBS DMEM). Then, $1.5 \mathrm{~mL}$ of the diluted supernatants was added to the Vero cell monolayers in T75 tissue culture flasks. After $1 \mathrm{~h}$, the inocula were discarded, and the cells were washed with PBS. Next, 2\% FBS DMEM was added, and the cells were incubated at $37{ }^{\circ} \mathrm{C}$ in a $5 \% \mathrm{CO}_{2}$ atmosphere. Supernatants containing viruses were collected when a CPE of $80-90 \%$ was observed. The culture supernatants were stored at $-80^{\circ} \mathrm{C}$.

Growth kinetics of Lopburi viruses in A549 and Vero cells A549 and Vero cells were infected with Lopburi01 and Lopburi02 viruses at MOI of 0.5 . Virus culture supernatants were collected at $0,6,12$, and $24 \mathrm{~h}$ after the virus adsorption step and subjected to virus titration in Vero cells.

\section{Viral resistance to temperature, chloroform and acid}

Viral resistance to temperature, chloroform and acid was determined via end-point viral titration in Vero cells. For temperature treatment, the viral culture 
supernatants were incubated at $50{ }^{\circ} \mathrm{C}, 60{ }^{\circ} \mathrm{C}$ or $70{ }^{\circ} \mathrm{C}$ for $1 \mathrm{~h}$ prior to viral titration. The supernatant stored at $4^{\circ}$ $\mathrm{C}$ was used as a control. For chloroform treatment, the viral culture supernatants were mixed with chloroform at a ratio of $1: 1$ for 30 or $60 \mathrm{~min}$. The mixtures were subsequently centrifuged at $600 \times g$ for $5 \mathrm{~min}$, and the upper aqueous phases containing viruses were collected for viral titration. The untreated supernatant was used as a control. For $\mathrm{pH}$ treatment, the viral culture supernatants were mixed with Mcllvaine's phosphate/citrate buffer $\mathrm{pH} 3$ or $\mathrm{pH} 5$ at a ratio of 1:10 [38] and incubated for $20 \mathrm{~h}$ at room temperature. Supernatant mixed with PBS ( $\mathrm{pH}$ 7.2) was used as a control. Viral resistance to heat, chloroform and acid was determined by comparing the $\mathrm{TCID}_{50}$ between treated and untreated samples.

\section{Viral titration}

The virus culture supernatants were serially diluted 10 -fold in 2\% FBS DMEM. Fifty microlitres of the diluted viruses were added to Vero cell monolayers cultured in a 96-well plate (total volume, $200 \mu \mathrm{L}$ ). The cultures were incubated at $37{ }^{\circ} \mathrm{C}$ in a $5 \% \mathrm{CO}_{2}$ atmosphere. The CPE was assessed daily until day 3 as an end-point compared with that in control wells. The titration was performed in quadruplicate wells for each viral dilution. $\mathrm{TCID}_{50} / \mathrm{mL}$ was calculated using the Spearman and Kärber algorithm [39].

\section{Electron microscopy}

Vero cells infected with the Lopburi02 virus were collected by centrifugation at $1000 \times \mathrm{g}$ for $15 \mathrm{~min}$ at $4{ }^{\circ} \mathrm{C}$. Primary and secondary fixations of the pellet were achieved via a 1 -h exposure to $2.5 \%$ glutaraldehyde and $1 \%$ osmium tetroxide in $0.1 \mathrm{M}$ sucrose phosphate buffer, respectively. After washing, the pellet was dehydrated via a graded ethanol series, infiltrated in LR White resin $\left(E^{\circ} S^{\circ}\right.$, embedded in capsule beams and finally polymerised at $65{ }^{\circ} \mathrm{C}$ for $48 \mathrm{~h}$. All embedded cells were sectioned at $100-\mathrm{nm}$ thickness and stained with uranyl acetate and lead citrate. The specimen was examined under a transmission electron microscope (HT7700; Hitachi, Japan).

\section{Virus concentration by ultracentrifugation for protein preparation}

Fifty millilitres of the virus supernatant cultured in Vero cells were collected, and cell debris was removed by centrifugation at $1000 \times g$ for $15 \mathrm{~min}$ at $4{ }^{\circ} \mathrm{C}$. Viruses in the supernatant were concentrated by ultracentrifugation in polycarbonate centrifuge bottles (no. 355603, Beckman Coulter) using a Beckman L7-65 ultracentrifuge (rotor $70.1 \mathrm{Ti}$ ) set at $35,000 \mathrm{rpm}$ for $1.5 \mathrm{~h}$ at $4{ }^{\circ} \mathrm{C}$. After ultracentrifugation, pellets containing viruses were processed for mass spectrometric analysis via re-suspension in lysis buffer $(1 \% \mathrm{NaCl}, 1 \%$ SDS and $1 \%$ Triton-X) to produce a virus protein lysate.

\section{LC-MS/MS}

The virus protein lysate was size-separated via $12 \%$ SDS-PAGE, and the gel was stained with the Coomassie brilliant blue G250 solution (Bio-Rad). The gel was cut along its length into 15 pieces (Fig. 5), and each piece was cut into equal small cubes and separately de-stained with a de-staining solution $\left[50 \mathrm{mM} \mathrm{NH}_{4} \mathrm{HCO}_{3}, 50 \%(\mathrm{v} / \mathrm{v})\right.$ acetonitrile $(\mathrm{ACN})]$. Gel cubes containing proteins were treated with $5 \mathrm{mM}$ dithiothreitol (DTT) (GE Healthcare) and alkylated in $250 \mathrm{mM}$ iodoacetamide (IAM) (GE Healthcare). The gels were then incubated for $30 \mathrm{~min}$ in the dark prior to dehydrating with $200 \mathrm{~mL}$ of $\mathrm{ACN}$ and digesting with trypsin $(100 \mathrm{ng} / \mathrm{mL})$ (Sigma-Aldrich). After tryptic digestion, peptides were extracted from the gels using 50\% (v/v) $\mathrm{ACN}$ and dried using a vacuum evaporator. The peptides were resuspended in $0.1 \%$ formic acid and analysed using a MicroToF Q II mass spectrometer (Bruker). The front end of the mass spectrometer was coupled to an Ultimate 3000 nano-LC system (Dionex). After separation, peptide fractions were automatically infused into the mass spectrometer. LC-MS/MS raw data files were generated and converted into mascot generic format (.mgf) files using DataAnalysis $^{\mathrm{Tm}}$ software version 3.4. The mgf files were searched using the Mascot program version 2.4.1 (Matrix Science) against the US National Center for Biotechnology Information (NCBI) database. The organism for searching was set as 'virus'. The maximum number of missed cleavages was set to 1 . Peptide tolerance and tandem MS tolerance were set to 1.2 and $0.6 \mathrm{Da}$, respectively. The fixed modification was set to cysteine carbamidomethylation, and variable modification included methionine oxidation. All reported peptides showed a more than $95 \%$ confidence level.

\section{Orthoreovirus RT-PCR for whole-genome sequencing and virus detection}

For amplification of orthoreovirus genome segments for nucleotide sequencing, total RNA was extracted from $140 \mu \mathrm{L}$ of viral culture supernatants using a QIAamp Viral RNA Mini Kit. RT-PCR using QIAGEN OneStep RT-PCR Kit was performed to amplify overlapping fragments of PCR products for each orthoreovirus genome segment. Primers for orthoreovirus whole-genome amplification were based on published sequences of the Melaka orthoreovirus and provided in Additional file 1: Table S1. RT-PCR was performed in mixtures containing 1× QIAGEN OneStep RT-PCR buffer, $0.4 \mathrm{mM}$ dNTPs, $0.6 \mu \mathrm{M}$ each of forward and reverse primers, 20 units of RNaseOUT $^{\mathrm{TN}}$ Recombinant Ribonuclease Inhibitor (Invitrogen), $1 \mu \mathrm{L}$ of QIAGEN OneStep RT-PCR Enzyme Mix and $3 \mu \mathrm{L}$ of RNA in a total volume of $25 \mu \mathrm{L}$. The 
RT-PCR protocol was $50{ }^{\circ} \mathrm{C}$ for $30 \mathrm{~min}$ for the reverse transcription step followed by $95^{\circ} \mathrm{C}$ for $15 \mathrm{~min}, 40$ cycles of $95{ }^{\circ} \mathrm{C}$ for $30 \mathrm{~s}, 50{ }^{\circ} \mathrm{C}$ for $30 \mathrm{~s}$ and $72{ }^{\circ} \mathrm{C}$ for $45-90 \mathrm{~s}$ (depending on the product length; approximately $1 \mathrm{~min} /$ $1 \mathrm{~kb}$ ) and a final extension step of $72{ }^{\circ} \mathrm{C}$ for $10 \mathrm{~min}$.

For orthoreovirus detection in monkey faecal samples, RNA extracted from $140 \mu \mathrm{L}$ of the $30 \%$ faecal solutions was subjected for the first step RT-PCR with primers S1 Reo1 F and S1 Reo1 R (Additional file 1: Table S1) as mentioned above. A semi-nested PCR was performed with primers S1 Reo1 F and S1 Reo1 nested R (5'GCCT GACATATCCGCGRGTT3') in a reaction containing $1 \times$ Standard PCR buffer, $0.2 \mathrm{mM}$ dNTPs, $0.2 \mu \mathrm{M}$ each of forward and reverse primers, 2.5 units of Taq DNA polymerase (New England BioLabs) and $2 \mu \mathrm{L}$ of the first step RT-PCR product in a total volume of $25 \mu \mathrm{L}$. The reaction condition was $95{ }^{\circ} \mathrm{C}$ for 2 min followed by 30 cycles of $95{ }^{\circ} \mathrm{C}$ for $30 \mathrm{~s}, 50{ }^{\circ} \mathrm{C}$ for $30 \mathrm{~s}$ and $72{ }^{\circ} \mathrm{C}$ for $30 \mathrm{~s}$ and a final extension at $72{ }^{\circ} \mathrm{C}$ for $10 \mathrm{~min}$. The RT-PCR and semi-nested PCR product sizes were 661 and $276 \mathrm{bp}$, respectively. PCR products were resolved by gel electrophoresis in $1.5 \%$ agarose gels and observed under a UV transilluminator.

\section{Hepatitis E semi-nested RT-PCR}

RT-PCR for detection of HEV in monkey faecal samples was performed with primers specific for the open-reading frame (ORF) 1 of HEV [37]. The RT-PCR reactions contained $1 \times$ OneStep RT-PCR buffer, 0.4 mM dNTPs, $0.6 \mu \mathrm{M}$ each of forward (HE61; 5'-CACRTATGTGGTC GAYGCCATGGAG-3') and reverse primers (HE51; 5'-GCCKRACYACCACAGCATTCG3-3'), 20 units of RNaseOUT $^{\mathrm{TM}}$ Recombinant Ribonuclease Inhibitor (Invitrogen, Thermo Fisher Scientific), $1 \mu \mathrm{L}$ of QIAGEN OneStep RT-PCR Enzyme Mix and $10 \mu \mathrm{L}$ of RNA in a total volume of $25 \mu \mathrm{L}$. The reaction protocol was $50{ }^{\circ} \mathrm{C}$ for $30 \mathrm{~min}$ for reverse transcription followed by $95{ }^{\circ} \mathrm{C}$ for $15 \mathrm{~min}, 45$ cycles of $95^{\circ} \mathrm{C}$ for $15 \mathrm{~s}, 55^{\circ} \mathrm{C}$ for $30 \mathrm{~s}$ and $72^{\circ}$ $\mathrm{C}$ for $30 \mathrm{~s}$ and a final extension at $72{ }^{\circ} \mathrm{C}$ for $10 \mathrm{~min}$. Products from the first-round RT-PCR were subjected to semi-nested PCR in reactions containing $1 \times$ Standard PCR buffer, $0.2 \mathrm{mM}$ dNTPs, $0.2 \mu \mathrm{M}$ each of forward (HE50; 5' -AAGGCTCCTGGCRTYACWAC-3') and reverse primers (HE51), 2.5 units of Taq DNA polymerase (New England BioLabs) and $0.5 \mu \mathrm{L}$ of the first step RT-PCR product in a total volume of $25 \mu \mathrm{L}$. The reaction condition was $95^{\circ} \mathrm{C}$ for 2 min followed by 20 cycles of $94{ }^{\circ} \mathrm{C}$ for $15 \mathrm{~s}, 60{ }^{\circ} \mathrm{C}$ for $30 \mathrm{~s}$ and $72{ }^{\circ} \mathrm{C}$ for $15 \mathrm{~s}$ and a final extension at $72{ }^{\circ} \mathrm{C}$ for $10 \mathrm{~min}$. The expected product sizes of the first step RT-PCR and semi-nested PCR were 125 and $85 \mathrm{bp}$, respectively. The products were resolved by gel electrophoresis in 2\% agarose gels and observed under a UV transilluminator. RNA from HEV-positive human faeces was used as a positive control. Nucleotide sequencing was performed using the nested PCR products to confirm amplification of the HEV sequence.

\section{PCR detection of other viruses}

PCR for herpesvirus detection [40] and RT-PCR for enterovirus detection [41] were performed as previously described. Rotavirus, enteric adenovirus, norovirus and astrovirus were detected using a multiplex RT-PCR kit (Seeplex ${ }^{\oplus}$ Diarrhea-V ACE detection, Seegene) according to the manufacturer's instructions.

\section{Nucleotide sequencing and phylogenetic analysis}

RT-PCR product bands of expected size were excised from agarose gels and purified using a PureLink ${ }^{\circledR}$ Quick Gel Extraction Kit (Invitrogen). The purified products were submitted for direct nucleotide sequencing in two directions using forward and reverse primers by the Bioneer Corporation (Republic of Korea). To obtain nucleotide sequences at the $5^{\prime}$ and $3^{\prime}$ ends of the virus genome segments, PCR fragments were cloned into a $\mathrm{PGEM}^{\circ}-\mathrm{T}$ Easy vector (Promega) and sequenced from universal primer sites inside the vector. Nucleotide sequences were processed using BioEdit version 7.0.4.1. Sequence contigs derived from the two-directional sequencing were joined using the Contig Assembly Program. Basic Local Alignment Search Tool (BLAST) searches were used to determine the identities of the nucleotide sequences in comparison with those deposited in the NCBI GenBank nucleotide database. The nucleotide sequences were aligned using ClustalW. Phylogenetic trees were constructed in the MEGA 5 program. A maximum likelihood method based on Tamura-Nei model with 1000 bootstrap replicates was applied. The percent sequence identity was determined using the Sequence Identity Matrix function in BioEdit.

\section{Monkey species identification}

DNA was extracted from monkey faecal samples using QIAamp Stool DNA Mini kit according to manufacturer's recommendations. A mitochondrial 12S rRNA gene sequence of approximately 400 bp was amplified using PCR with primers 12S-L1091 5'-AAAAAGCTT CAAACTGGGATTAGATACCCCACTAT-3' and 12SH1478 5' -TGACTGCAGAGGGTGACGGGCGGTGT GT-3' [42]. After visualisation on a $1.5 \%$ agarose gel, amplicons were subjected for nucleotide sequencing and the host species was analysed by BLAST searching of the nucleotide sequences with NCBI database.

\section{Additional file}

Additional file 1: Table S1. Primers for the orthoreovirus whole-genome sequencing, designed based on sequences of the Melaka orthoreovirus. Sequences of primers for the orthoreovirus whole-genome sequencing. (DOC $85 \mathrm{~kb}$ ) 


\section{Abbreviations}

2D: Two-dimensional; ACN: Acetonitrile; ARV: Avian orthoreovirus; BLAST: Basic Local Alignment Search Tool; CPE: Cytopathic effect; DMEM: Dulbecco's modified Eagle's medium; DTT: Dithiothreitol; FBS: Foetal bovine serum; HEV: Hepatitis E virus; HPLC-MS/MS: High-performance liquid chromatography-tandem mass spectrometry; IAM: lodoacetamide; ITS$X$ : Insulin-transferrin-selenium-ethanolamine; LC: Liquid chromatography; LCMS/MS: Liquid chromatography-tandem mass spectrometry; MEM: Minimum essential medium; MRV: Mammalian orthoreovirus; MS: Mass spectrometry; MS/MS: Tandem MS; NBV: Nelson Bay orthoreovirus; NCBI: National Center for Biotechnology Information; NHPs: Non-human primates; ORF: Openreading frame; PRV: Pteropine orthoreovirus; TOF MS: Time-of-flight mass spectrometry

\section{Acknowledgements}

This work was supported by the Faculty of Tropical Medicine Research Fund, Mahidol University, Thailand and a program of the Japan Initiative for Global Research Network on Infectious Diseases, directed by the Ministry of Education, Culture, Sports, Science, and Technology of Japan. We thank Ms. Jarinee Tongshoob for her assistance in a preparation of the revised manuscript. We would like to thank Enago (www.enago.com) for English editing.

\section{Funding}

The work was financially supported by the Faculty of Tropical Medicine Research Fund, Mahidol University, Thailand and a program of the Japan Initiative for Global Research Network on Infectious Diseases, directed by the Ministry of Education, Culture, Sports, Science, and Technology of Japan. The funding agencies have no role in the design of the study and collection, analysis, and interpretation of data and in writing the manuscript.

\section{Availability of data and materials}

Nucleotide sequence data are deposited in GenBank database (accession numbers KY751007-KY751026). These accession numbers are also provided in the main text. Primer sequences are provided in the main text or in the Additional file 1: Table S1.

\section{Authors' contributions}

NK designed the study and conducted the majority of the experiments on virus detection, virus culture, virus titration and whole-genome sequence analysis and wrote the manuscript. OR gave advice for the experimental design and discussion regarding mass spectrometry and analysed the mass spectrometry data. TO co-ordinated the study, gave advice and took the cell pictures. SA performed the transmission electron microscopy. AR and NT assisted in the PCR product visualisation and preparation of $P C R$ products for nucleotide sequencing. TT performed the LC-MS/MS experiment. PL co-ordinated the study. AM and HM collected the samples. TY and PY assisted in the virus physicochemical property testing. All authors read and approved the final manuscript.

\section{Ethics approval and consent to participate}

Not applicable. The samples were defecated monkey faeces collected from grounds. No animal was contacted or harmed in this study.

\section{Consent for publication}

\section{Not applicable.}

\section{Competing interests}

The authors declare that they have no competing interests.

\section{Publisher's Note}

Springer Nature remains neutral with regard to jurisdictional claims in published maps and institutional affiliations.

\section{Author details}

'Department of Microbiology and Immunology, Faculty of Tropical Medicine, Mahidol University, 420/6 Ratchawithi Road, Ratchathewi, Bangkok 10400, Thailand. ${ }^{2}$ Department of Molecular Tropical Medicine and Genetics, Faculty of Tropical Medicine, Mahidol University, 420/6 Ratchawithi Road, Ratchathewi, Bangkok 10400, Thailand. ${ }^{3}$ Department of Veterinary Sciences, Faculty of Agriculture, University of Miyazaki, Gakuen-kibanadai-nishi-1-1, Miyazaki 889-2192, Japan. ${ }^{4}$ Mahidol-Osaka Center for Infectious Diseases
(MOCID), Research Institute for Microbial Diseases, Osaka University, 3-1 Yamadaoka, Suita, Osaka 565-0871, Japan. ${ }^{5}$ Department of Tropical Pathology, Faculty of Tropical Medicine, Mahidol University, 420/6 Ratchawithi Road, Ratchathewi, Bangkok 10400, Thailand. ${ }^{6}$ Department of Protozoology, Faculty of Tropical Medicine, Mahidol University, 420/6 Ratchawithi Road, Ratchathewi, Bangkok 10400, Thailand.

\section{Received: 19 September 2017 Accepted: 4 October 2018}

Published online: 17 October 2018

\section{References}

1. Abad FX, Pintó RM, Bosch A. Survival of enteric viruses on environmental fomites. Appl Environ Microbiol. 1994;60:3704-10.

2. Koopmans M, Duizer E. Foodborne viruses: an emerging problem. Int J Food Microbiol. 2004;90:23-41.

3. Day JM. The diversity of the orthoreoviruses: molecular taxonomy and phylogenetic divides. Infect Genet Evol. 2009;9:390-400.

4. Fauquet CM, Mayo MA, Maniloff J, Desselberger U, Ball LA. Virus taxonomy: eighth report of the international committee on taxonomy of viruses. London: Academic Press; 2005.

5. Chua KB, Voon K, Yu M, Keniscope C, Abdul Rasid K, Wang LF. Investigation of a potential zoonotic transmission of orthoreovirus associated with acute influenza-like illness in an adult patient. PLoS One. 2011;6:e25434.

6. Gard GP, Marshall ID. Nelson Bay virus. A novel reovirus. Arch Gesamte Virusforsch. 1973;43:34-42.

7. Pritchard LI, Chua KB, Cummins D, Hyatt A, Crameri G, Eaton BT, et al. Pulau virus; a new member of the Nelson Bay orthoreovirus species isolated from fruit bats in Malaysia. Arch Virol. 2006;151:229-39.

8. Chua KB, Crameri G, Hyatt A, Yu M, Tompang MR, Rosli J, et al. A previously unknown reovirus of bat origin is associated with an acute respiratory disease in humans. Proc Natl Acad Sci U S A. 2007;104:11424-9.

9. Chua KB, Voon K, Crameri G, Tan HS, Rosli J, McEachern JA, et al. Identification and characterization of a new orthoreovirus from patients with acute respiratory infections. PLoS One. 2008;3:e3803.

10. Cheng P, Lau CS, Lai A, Ho E, Leung P, Chan F, et al. A novel reovirus isolated from a patient with acute respiratory disease. J Clin Virol. 2009;45: 79-80.

11. Wong AH, Cheng PK, Lai MY, Leung PC, Wong KK, Lee WY, et al. Virulence potential of fusogenic orthoreoviruses. Emerg Infect Dis. 2012;18:944-8.

12. Yamanaka A, Iwakiri A, Yoshikawa T, Sakai K, Singh H, Himeji D, et al. Imported case of acute respiratory tract infection associated with a member of species nelson bay orthoreovirus. PLoS One. 2014;9:e92777.

13. Du L, Lu Z, Fan Y, Meng K, Jiang Y, Zhu Y, et al. Xi River virus, a new bat reovirus isolated in southern China. Arch Virol. 2010;155:1295-9.

14. Hu T, Qiu W, He B, Zhang Y, Yu J, Liang X, et al. Characterization of a novel orthoreovirus isolated from fruit bat, China. BMC Microbiol. 2014;14:293.

15. Lorusso A, Teodori L, Leone A, Marcacci M, Mangone I, Orsini M, et al. A new member of the Pteropine Orthoreovirus species isolated from fruit bats imported to Italy. Infect Genet Evol. 2015;30:55-8.

16. Taniguchi S, Maeda K, Horimoto T, Masangkay JS, Puentespina R Jr, Alvarez J, et al. First isolation and characterization of pteropine orthoreoviruses in fruit bats in the Philippines. Arch Virol. 2017;162:1529-39.

17. Calderaro A, Arcangeletti MC, Rodighiero I, Buttrini M, Gorrini C, Motta F, et al. Matrix-assisted laser desorption/ionization time-of-flight (MALDI-TOF) mass spectrometry applied to virus identification. Sci Rep. 2014;4:6803.

18. Lewis JK, Bendahmane M, Smith TJ, Beachy RN, Siuzdak G. Identification of viral mutants by mass spectrometry. Proc Natl Acad Sci U S A. 1998;95: 8596-601.

19. She YM, Haber S, Seifers DL, Loboda A, Chernushevich I, Perreault H, et al. Determination of the complete amino acid sequence for the coat protein of brome mosaic virus by time-of-flight mass spectrometry. Evidence for mutations associated with change of propagation host. J Biol Chem. 2001; 276:20039-47.

20. Pandey A, Mann M. Proteomics to study genes and genomes. Nature. 2000; 405:837-46.

21. Cooper B, Eckert D, Andon NL, Yates JR, Haynes PA. Investigative proteomics: identification of an unknown plant virus from infected plants using mass spectrometry. J Am Soc Mass Spectrom. 2003;14:736-41.

22. Pavio N, Meng XJ, Renou C. Zoonotic hepatitis E: animal reservoirs and emerging risks. Vet Res. 2010;41:46. 
23. Gonwong S, Chuenchitra T, Khantapura P, Islam D, Sirisopana N, Mason CJ Pork consumption and seroprevalence of hepatitis E virus, Thailand, 20072008. Emerg Infect Dis. 2014;20:1531-4.

24. Sa-nguanmoo P, Posuwan N, Vichaiwattana P, Wutthiratkowit N, Owatanapanich S, Wasitthankasem R, et al. Swine is a possible source of hepatitis $\mathrm{E}$ virus infection by comparative study of hepatitis A and $\mathrm{E}$ seroprevalence in Thailand. PLoS One. 2015;10:e0126184.

25. Wiratsudakul A, Sariya L, Prompiram P, Tantawet S, Suraruangchai D, Sedwisai $P$, et al. Detection and phylogenetic characterization of hepatitis $E$ virus genotype 3 in a captive wild boar in Thailand. J Zoo Wildl Med. 2012; 43:640-4.

26. Di Martino B, Di Profio F, Melegari I, Sarchese V, Robetto S, Marsilio F, et al. Detection of hepatitis E virus (HEV) in goats. Virus Res. 2016;225:69-72.

27. Aggarwal R, Kamili S, Spelbring J, Krawczynski K. Experimental studies on subclinical hepatitis E virus infection in cynomolgus macaques. J Infect Dis. 2001;184:1380-5.

28. Voon K, Tan YF, Leong PP, Teng CL, Gunnasekaran R, Ujang K, et al. Pteropine orthoreovirus infection among out-patients with acute upper respiratory tract infection in Malaysia. J Med Virol. 2015;87:2149-53.

29. Singh H, Shimojima M, Ngoc TC, Quoc Huy NV, Chuong TX, Le Van A, et al. Serological evidence of human infection with Pteropine orthoreovirus in Central Vietnam. J Med Virol. 2015;87:2145-8.

30. Wacharapluesadee S, Duengkae P, Rodpan A, Kaewpom T, Maneeorn P, Kanchanasaka B, et al. Diversity of coronavirus in bats from Eastern Thailand. Virol J. 2015;12:57.

31. Thanapongtharm W, Linard C, Wiriyarat W, Chinsorn P, Kanchanasaka B, Xiao $X$, et al. Spatial characterization of colonies of the flying fox bat, a carrier of Nipah virus in Thailand. BMC Vet Res. 2015;11:81.

32. Meng XJ. Hepatitis E virus: animal reservoirs and zoonotic risk. Vet Microbiol. 2010;140:256-65.

33. Meng XJ, Halbur PG, Shapiro MS, Govindarajan S, Bruna JD, Mushahwar IK, et al. Genetic and experimental evidence for cross-species infection by swine hepatitis E virus. J Virol. 1998;72:9714-21.

34. Zheng Y, Ge S, Zhang J, Guo Q, Ng MH, Wang F, et al. Swine as a principal reservoir of hepatitis $E$ virus that infects humans in eastern China. J Infect Dis. 2006;193:1643-9.

35. Grierson S, Heaney J, Cheney T, Morgan D, Wyllie S, Powell L, et al. Prevalence of hepatitis $E$ virus infection in pigs at the time of slaughter, United Kingdom, 2013. Emerg Infect Dis. 2015;21:1396-401.

36. Jackova A, Mandelik R, Novotny J, Salamunova S, Vilcek S. The incidence of hepatitis E virus in domestic pigs. Folia Veterinaria. 2017;61:65-70.

37. Kanai Y, Miyasaka S, Uyama S, Kawami S, Kato-Mori Y, Tsujjkawa M, et al. Hepatitis E virus in Norway rats (Rattus norvegicus) captured around a pig farm. BMC Res Notes. 2012;5:4.

38. Marina CF, Feliciano JM, Valle J, Williams T. Effect of temperature, pH, ion concentration, and chloroform treatment on the stability of invertebrate iridescent virus 6. J Invertebr Pathol. 2000;75:91-4.

39. Kangro H, Mahy B. Virology methods manual. London: Academic Press; 1996.

40. Black DH, Eberle R. Detection and differentiation of primate alphaherpesviruses by PCR. J Vet Diagn Investig. 1997;9:225-31.

41. Ngaosuwankul N, Thippornchai N, Yamashita A, Vargas RE, Tunyong W, Mahakunkijchareon Y, et al. Detection and characterization of enteric viruses in flood water from the 2011 Thai flood. Jpn J Infect Dis. 2013;66:398-403.

42. Mombo IM, Lukashev AN, Bleicker T, Brünink S, Berthet N, Maganga GD, et al. African non-human primates host diverse enteroviruses. PLoS One. 2017; 12:e0169067.

Ready to submit your research? Choose BMC and benefit from:

- fast, convenient online submission

- thorough peer review by experienced researchers in your field

- rapid publication on acceptance

- support for research data, including large and complex data types

- gold Open Access which fosters wider collaboration and increased citations

- maximum visibility for your research: over $100 \mathrm{M}$ website views per year

At BMC, research is always in progress.

Learn more biomedcentral.com/submissions 